\title{
Application of Animal Welfare on Dairy Cattle Livestock in Ternak Sukses Bersama, Deyeng Village, Ringinrejo District, Kediri Regency
}

\author{
Fidi Nur Aini Eka Puji Dameanti \\ Faculty of Veterinary Medecine \\ Brawijaya University \\ Malang, Indonesia \\ fididameanti88@gmail.com
}

\author{
Ani Setianingrum \\ Faculty of Veterinary Medecine \\ Brawijaya University \\ Malang, Indonesia \\ ani.pradeksa@gmail.com
}

\author{
Masdiana C. Padaga \\ Faculty of Veterinary Medecine \\ Brawijaya University \\ Malang, Indonesia \\ mdp.fkh@gmail.com
}

\author{
Manik Eirry Sawitri \\ Faculty of Husbandry \\ Brawijaya University \\ Malang, Indonesia \\ maniksawitri@gmail.com
}

\author{
Mira Fatmawati \\ Faculty of Veterinary Medecine \\ Brawijaya University \\ Malang, Indonesia \\ Mirafkh@gmail.com \\ Faris Ramadhanail \\ Faculty of Veterinary Medecine \\ Brawijaya University \\ Malang, Indonesia \\ rahmadhanailfaris@gamail.com
}

\begin{abstract}
This research aims to describe the application of animal welfare to dairy farmers. The research was conducted by field observation method using a structured questionnaire. The participants in the study was 13 people. The application of animal welfare in this study includes 3 aspects, they are: Feed Management (frequency of feeding and drinking, feed ration), Housing Management (type of cage, building type, cage capacity, cage area, cage base, isolation cage), Health Management (cleaning cage, exercise, history of vaccination and treatment, history of disease). Feed management results showed that 13 farmers used $38.5 \%$ pineapple cob as forage feed, $\mathbf{3 0 . 8 \%}$ used pineapple cob and naper grass mixture as forage feed, $15.4 \%$ used weeds and naper grass, and $7.7 \%$ used Corn cob with a mixture of naper grass and $7.7 \%$ gives only naper grass as forage. The frequency of feeding averaged twice a day $(53.8 \%)$ and three times a day $(30.8 \%)$. Housing management results the housing area of each farmer varies from $18 \mathrm{~m}^{3}$ to $100 \mathrm{~m}^{3}$ with an average of $24 \mathrm{~m}^{3}(23.1 \%)$ and $40 \mathrm{~m}^{3}(15.4 \%)$. Health management showed a history of Brucella vaccination (23.1\%), Brucella + Anthrax (46.2\%), and $30.8 \%$ of farmers did not vaccinate. Farmers do cage cleaning twice a day (76.9\%) and 3 times a day $(\mathbf{2 3 . 1 \%})$. The history of the disease there, 13 farmers in the village, said that their livestock had been affected (fever) BEF 76.9\%, Milk Fever (rheumatic) 15.4\% Mastitis $53.8 \%$ and Hypocalcemia, CLP (Corpus Luteum Persistent), Bloating (Bloat), Retensio Placenta, Abses, Cantengan (Paronchya) and Diarrhea as much as $7.7 \%$. The results of this study suggest the need for KIE (Communication, Information and Education) on a going basis to dairy farmers in Ternak Sukses Bersama, Deyeng Village, Ringinrejo District, and Kediri Regency.
\end{abstract}

Keywords-Animal welfare, Dairy cattle breeders, Kediri Regency

\section{INTRODUCTION}

According to Republic of Indonesian government regulation No. 95 of 2012 concerning Veterinary Public Health and Animal Welfare, the definition of Animal Welfare is relating to the physical and mental state of animals based on the animal's behavior that need to be applied and enforced to protect animals from any improper treatment of animals used by humans. Animals Welfare adheres to the principle of 'Five Freedoms' that was declared in 1979 by the Animal Welfare Board in the United Kingdom (FAWC 1993). The Animal Welfare was internationally recognized declaration and adopted by the World Organization for Animal Health (OIE 2010), the principle consists of; Freedom from hunger and thirst, freedom from discomfort, freedom from pain, injury and disease, freedom from fear and distress, freedom to express normal behavior.

Dairy cows are farms animals that need intensive treatment in order to produce milk that has stable quality and quantity. Be sides the feed that need more attention, management of safeguarding and health also need more attention by cattle breeders. Safegurding and nutrition is no good it can cause productivity and diseases that can reduce production of milk in dairy cows itself (Kusumawatingrum,2014).

The diseases in livestock is very damage for breeder because it will be reduced production of milk and reproducing, increase medical cost, the risk of death of livestock, as well as a certain diseases that can be infect to other livestock and human (Anggreani and Mariana, 2016).

\section{MATERIALS AND METHODS}

This research was conducted using the field observation method using a structured questionnaire. The numbers of dairy farmers in current study was 13 participant whom joint success Livestock Group, Deyeng village, Ringinrejo district, Kediri regency. The implementation of Animals Welfare in current study includes 3 aspects, namely: management of feed (frequency of feeding and drinking, feed rations), Management of Housing (type of cage, building, capacity of cage, area of cage, base of cage, and isolation of cage), management of health (cleaning of cage, exercise, vaccination and treatment, disease history). 


\section{RESULTS}

The result of management of feeds showed that 13 breeders use $38,5 \%$ pineapple cob as forage, 30,8\% use pineapple cob and mixed with naper grass as forege, $15,4 \%$ use weeds and naper grass, and 7,7\% use corn grass mixed with naper grass and $7,7 \%$ only give naper grass as forage.

TABLE 1. Data Of Feed Management

\begin{tabular}{|c|c|c|c|}
\hline No. & $\begin{array}{l}\text { The rating of feed } \\
\text { parameters }\end{array}$ & $\begin{array}{l}\text { Number } \\
\text { of } \\
\text { breeders }\end{array}$ & $\begin{array}{l}\text { Percentage } \\
(13 \\
\text { breeders })\end{array}$ \\
\hline 1 & \multicolumn{3}{|l|}{ Forage } \\
\hline & Pineapple cob & 5 & $38,5 \%$ \\
\hline & $\begin{array}{l}\text { Pineapple cob } \\
\text { + naper grass }\end{array}$ & 4 & $30,8 \%$ \\
\hline & weeds + naper grass & 2 & $15,4 \%$ \\
\hline & $\begin{array}{l}\text { Corn grass }+ \\
\text { naper grass }\end{array}$ & 1 & $7,7 \%$ \\
\hline & Naper grass & 1 & $7,7 \%$ \\
\hline \multirow[t]{6}{*}{2} & \multicolumn{3}{|l|}{ Concentrate } \\
\hline & $\begin{array}{ll}\text { Concentrate } & + \\
\text { Soybean flour } & \end{array}$ & 4 & $30,8 \%$ \\
\hline & Concentrate & 3 & $23,1 \%$ \\
\hline & $\begin{array}{l}\text { Concentrate }+ \\
\text { Soybean flour } \\
+\quad \text { Sweet } \\
\text { Potato flour }\end{array}$ & 4 & $30,8 \%$ \\
\hline & $\begin{array}{l}\text { Soybean flour } \\
+\quad \text { Sweet } \\
\text { Potato flour } \\
\end{array}$ & 1 & $7,7 \%$ \\
\hline & Soybean flour & 1 & $7,7 \%$ \\
\hline \multirow[t]{2}{*}{3} & \multicolumn{3}{|l|}{ Drinking } \\
\hline & Ad libitum & 13 & $100 \%$ \\
\hline \multirow[t]{5}{*}{4} & \multicolumn{3}{|l|}{ Frequency of feed } \\
\hline & Once a day & 1 & $7,7 \%$ \\
\hline & Twince a day & 7 & $53,8 \%$ \\
\hline & Three a day & 4 & $30,8 \%$ \\
\hline & Four a day & 1 & $7,7 \%$ \\
\hline
\end{tabular}

The use of pineapple cob as a forage is due to the high of forage requirements for livestock and the low naper grass in the area. The use of pineapple cob is also assessed as a movement for the utlizalation of waste of pineapple plantations and for sustainable availability. According to Ringgita (2015), stated that in terms of nutrition of pineapple leaves $(9,1 \%$ crude protein, fiber $23,6 \%$, ash $4,9 \%$, crude fat $1,6 \%$, and BETN 60,8\%). Concentrate extending data obtained has various formulation from 13 breeders, $30,8 \%$ give mixed concentrate with soybean flour, $23,1 \%$ give only concentrate, 30,8 use mixed concentrate, sweet potato and soybean flour, and $7,7 \%$ give soybean flour mixed sweet potato flour, and $7,7 \%$ give only sweet potato flour. Frequency of feeding on average twice a day $(53,8 \%)$, and three time a day $(0,8 \%)$. Meanwhile, according to Siregar (2001), frequency of feeding four time a day was able to increase the produce of milk up to $54,8 \%$. Based on the result of data it can be explained that 13 breeders have fullfilled the implementation of the first point of "five freedom" which is freedom from hunger and thirst due to adequate feeding ad libitum like water in the form of uncontaminated water.

Management of housing can be one aspect of implementation of Animal Welfare especially as assessment of freedom from discomfort and freedom from fear and sress. The data from inverviews on management of housing that can be see in table 2 .

The results of this study suggest the need for KIE (Communication, Information and Education) on a going basis to dairy farmers in sucsess, Deyeng Village, Ringinrejo District, and Kediri Regency.

TABLE II. The DAta Of MANAGEMENT OF Housing

\begin{tabular}{|c|c|c|c|}
\hline No. & $\begin{array}{l}\text { The Rating of } \\
\text { Cage } P\end{array}$ & $\begin{array}{l}\text { Number of } \\
\text { Breeders }\end{array}$ & $\begin{array}{l}\text { Percentage } \\
(13 \\
\text { Breeders })\end{array}$ \\
\hline \multirow[t]{2}{*}{1} & \multicolumn{3}{|l|}{ Types of housing } \\
\hline & Double & 13 & $100 \%$ \\
\hline \multirow[t]{2}{*}{2} & \multicolumn{3}{|l|}{ Tyoes of building } \\
\hline & Permanent & 13 & $100 \%$ \\
\hline \multirow[t]{9}{*}{3} & \multicolumn{3}{|l|}{ Capacity of housing } \\
\hline & 6 tails & 2 & $15,4 \%$ \\
\hline & 9 tails & 1 & $7,7 \%$ \\
\hline & 10 tails & 2 & $15,4 \%$ \\
\hline & 12 tails & 3 & $23,1 \%$ \\
\hline & 14 tails & 1 & $7,7 \%$ \\
\hline & 16 tails & 2 & $15,4 \%$ \\
\hline & 20 tails & 1 & $7,7 \%$ \\
\hline & 24 tails & 1 & $7,7 \%$ \\
\hline \multirow[t]{3}{*}{4} & \multicolumn{3}{|l|}{ Base of housing } \\
\hline & Rubber & 12 & $92,3 \%$ \\
\hline & Cement & 1 & $7,7 \%$ \\
\hline \multirow[t]{10}{*}{5} & \multicolumn{3}{|l|}{ Area of Housing } \\
\hline & $18 \mathrm{~m}^{3}$ & 1 & $7,7 \%$ \\
\hline & $24 \mathrm{~m}^{3}$ & 3 & $23,1 \%$ \\
\hline & $40 \mathrm{~m}^{3}$ & 2 & $15,4 \%$ \\
\hline & $48 \mathrm{~m}^{3}$ & 1 & $7,7 \%$ \\
\hline & $56 \mathrm{~m}^{3}$ & 1 & $7,7 \%$ \\
\hline & $60 \mathrm{~m}^{3}$ & 1 & $7,7 \%$ \\
\hline & $70 \mathrm{~m}^{3}$ & 1 & $7,7 \%$ \\
\hline & $80 \mathrm{~m}^{3}$ & 1 & $7,7 \%$ \\
\hline & $100 \mathrm{~m}^{3}$ & 2 & $15,4 \%$ \\
\hline \multirow[t]{3}{*}{6} & \multicolumn{3}{|l|}{ Isolation of Housing } \\
\hline & Availability & 9 & $69,2 \%$ \\
\hline & Not availability & 4 & $30,8 \%$ \\
\hline
\end{tabular}

\section{DISCUSSION}

According to data on the results that have been obtained from 13 breeders. The house area of each farmer varies, ranging from $18 \mathrm{~m}^{3}$ to $100 \mathrm{~m}^{3}$ with an average of 24 $\mathrm{m}^{3}(23,1 \%)$ and $40 \mathrm{~m}^{3}(15,4 \%)$. Isolation of cages are not owned by every breeder on his farm, $69.2 \%$ of breeders 
provide isolation facilities while $30,8 \%$ do not have isolation of cages. The foundation of cage used by breeders in general has used rubber $(92,3 \%)$ and only one breeder that not used rubber and used cement cage $(7,7 \%)$. Based on Aziz (2013), the use of a rubber can protect and reduce the occurrence of laminitis or inflammation of cow's nails.

TABLE III. COMPARISON OF AREA With CAPACITY OF CAGES

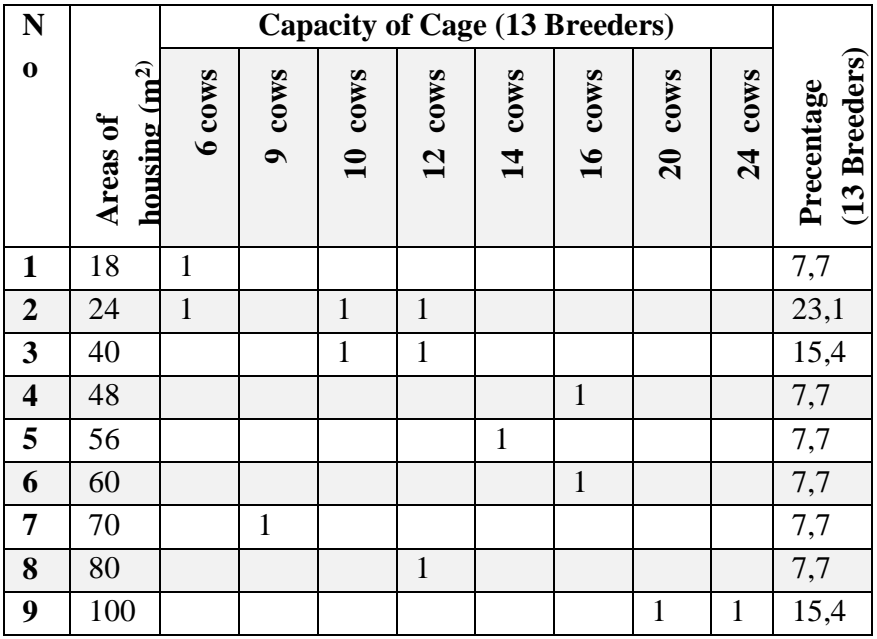

From the comparison table between the area with the capacity of cage, it is obatined that the data of the farm with an area of $18 \mathrm{~m}^{2}$ cage was used for 6 cows $(7,7 \%), 24$ $\mathrm{m}^{2}$ was used for 6,10 , and 12 cows $\left(23,1 \% 0,40 \mathrm{~m}^{2}\right.$ was used for 10 and 12 cows $(15,4 \%), 48 \mathrm{~m}^{2}$ was used for 16 cows $(7,7 \%), 56 \mathrm{~m}^{2}$ was used for 14 cows $(7,7 \%), 60 \mathrm{~m}^{2}$ was used 16 cows $(7,7 \%), 70 \mathrm{~m}^{2}$ was used for 9 cows $(7,7 \%), 80 \mathrm{~m}^{2}$ was used for 12 cows $(7,7 \%)$, and $100 \mathrm{~m}^{2}$ was used for 20 and 24 cows $(15,4 \%)$. According to Albiantono (2016), in an ideal dairy cage system, the zise of the cage should provide an area of around $3 \mathrm{~m}^{2}$ for one cow. From the comparative data it can be explained that the most of breeders has fulfilled the ideal standard of houisng as fulfilling the implementation of freedom from discomfort.

Based on the result of data it can be explaind that 13 breeders have fulfilled the assessment of freedom from discomfrot and freedom from fear and pressure. In general, the types of good housing system is permanent, the type of double housing (head to head) and (tail to tail). Most of breeders use cages that are semi-open or without walls, thus, ventilation is good, temperatures are quit cool, freedom from predator reach and sunlight can enter the cage (Lestari, 2015).Management of Animals Health can be one aspect of the implementation of animal welfare, especially as an assessment of freedom from pain, injury and disease and an assessment of freedom to express normal behavior. The data from inteviews on management of health assessment can be seen in Table 4 .
TABLE 4. MANAGEMENT OF HEALTH

\begin{tabular}{|c|c|c|c|}
\hline No. & $\begin{array}{l}\text { The rating of parameter } \\
\text { of Health and cattle of } \\
\text { safeguarding }\end{array}$ & $\begin{array}{l}\text { Number of } \\
\text { Breeders }\end{array}$ & $\begin{array}{l}\text { Percentage } \\
(13 \\
\text { Breeders }) \\
\end{array}$ \\
\hline 1. & \multicolumn{3}{|l|}{ Exercise } \\
\hline & Rarely & 4 & $30,8 \%$ \\
\hline & Never & 7 & $53,8 \%$ \\
\hline & Ever & 1 & $7,7 \%$ \\
\hline & In cows pregnant & 1 & $7,7 \%$ \\
\hline 2. & \multicolumn{3}{|c|}{ Frequency of cleaning cage } \\
\hline & Twice a day & 10 & $76,9 \%$ \\
\hline & There time a day & 3 & $23,1 \%$ \\
\hline 3. & \multicolumn{3}{|l|}{ Giving Vitamins } \\
\hline & B complex & 12 & $92,3 \%$ \\
\hline & B complex + Vit E & 1 & $7,7 \%$ \\
\hline 4. & \multicolumn{3}{|l|}{ Giving Vaccination } \\
\hline & Brucella & 3 & $23,1 \%$ \\
\hline & Brucella + Anthrax & 6 & $46,2 \%$ \\
\hline & No Vaccination & 4 & $30,8 \%$ \\
\hline 5. & \multicolumn{3}{|l|}{ Giving Worm Medicine } \\
\hline & On Pedet & 3 & $23,1 \%$ \\
\hline & Not given & 2 & $15,4 \%$ \\
\hline & Once every 3 months & 1 & $7,7 \%$ \\
\hline & Once every 6 months & 7 & $53,8 \%$ \\
\hline 6. & \multicolumn{3}{|l|}{ Use of Antibiotics } \\
\hline & Penstrep & 11 & $84,6 \%$ \\
\hline & Not given & 2 & $15,4 \%$ \\
\hline 7. & \multicolumn{3}{|l|}{ Disease History } \\
\hline & Fever & 10 & $76,9 \%$ \\
\hline & Milk Fever & 2 & $15,4 \%$ \\
\hline & Mastitis & 7 & $53,8 \%$ \\
\hline & Hipocalcemia & 1 & $7,7 \%$ \\
\hline & $\begin{array}{ll}\text { Corpus } & \text { Luteum } \\
\text { Persisten } & \\
\end{array}$ & 1 & $7,7 \%$ \\
\hline & Bloat & 1 & $7,7 \%$ \\
\hline & Retensio Placenta & 1 & $7,7 \%$ \\
\hline & Abscess & 1 & $7,7 \%$ \\
\hline & Paronchya & 1 & $7,7 \%$ \\
\hline & Liquid Stool (Diarhea) & 1 & $7,7 \%$ \\
\hline
\end{tabular}

Cleaning cage and cattle is done by breeders with frequency of cleaning cages twice a day $(76.9 \%)$ and three time a day (23.1\%). According to Sugianto (2008), cleaning the cage is a requirement to prevent the outbreak of disease that occurs in the cage so that the health of dairy cows is maintained. In addition to the cleanliness of the cage, grazing or exercise in dairy cows is also related to maintaining livestock health. Exercises performed on cattle herds have different needs according to farmers, $30.8 \%$ of breeders rarely exercise on their cattle, $7.7 \%$ have done exercise on their cattle and only performed on older pregnant cows, and $53.8 \%$ have never doing exercises on the livestock because the breeders did not have time to do shepherds on their livestock. According to Sudono (2003), exercise or exercise is needed by cows every day for one to two hours in the field, to get sunlight. The removal of the mother from the cage is very useful because it will improve appetite as well as improve digestibility and can help block the udder during delivery. The results of interviews about 
vaccination and treatment history and disease history can be concluded that all breeders routinely provide Vitamin B Complex to their livestock and only $7.7 \%$ of breeders provide a mixture with Vitamin E. The frequency of administration of worm medicine in dairy cows' ranges between 3 months $(7.7 \%)$ and once every 6 months $(53.8 \%)$ also $23.1 \%$ of breeders only gave calves and $15.4 \%$ did not give worm medicine to their animals. Vaccinations carried out by the Success Together cattle group were Brucella (23.1\%), Brucella + Anthrax (46.2\%), and $30.8 \%$ of farmers did not vaccinate. The antibiotics given were in the form of Penstrep (84.6\%) and $15.4 \%$ of farmers never gave antibiotics to their animals. Knowledge of the procedures and doses of drugs, especially antibiotics, is very important so as not to leave residues on products of animal origin (Lestari, 2001). Therefore, the provision of medicines should be given by veterinarians, while a history of dairy cow disease from 13 breeders as many as $76.9 \%$ of dairy farmers have experienced fever (BEF) in their cattle, $15.4 \%$ have rheumatism (Milk Fever), 53, 8\% had a history of mastitis, and $7.7 \%$ had a history of diseases such as Hypocalcemia, CLP (Corpus Luteum Persistent), Bloating (Bloat), Retention of Placenta, Abscess, Cantengan (Paronchya) and Diarrhea.

\section{ACKNOWLEDGMENT}

Institute of research and community service of Brawijaya University.

\section{REFERENCES}

[1] Albiantono, L., \& Sambodho, P. (2016). Manajemen Perkandangan Sapi Perah pada CV. Capita Farm di Desa Sumogawe, Kecamatan Getasan, Semarang. Fakultas Peternakan Dan Pertanian. Universitas Diponegoro.

[2] Anggraeni, A., \& Mariana, E., 2016. Evaluasi Aspek Teknis Pemeliharaan Sapi Perah Menuju Good Dairy Farming Practices pada Peternakan Sapi Perah Rakyat Pondok Ranggon. Jurnal Agripet, 16(2), 90-96.

[3] Aziz, A. S., Surjowardojo, P., \& Sarwiyono, S. 2013. Hubungan Bahan Dan TingkatKebersihan Lantai Kandang Terhadap Kejadian Mastitits Melalui Uji California Mastitis Test (CMT) di Kecamatan Tutur Kabupaten Pasuruan Jawa Timur.Journal of Tropical Animal Production, 14(2), 72-81.

[4] Kusumawatiningrum, B., 2014. TA: Rancang Bangun Sistem Informasi Manajemen Reproduksi Sapi Perah Berbasis Mobile (Studi Kasus: PT. Drajat Farm), Stikom Surabaya.

[5] Lestari, N. F. 2015. Hubungan Antara Penerapan Good Dairy Farming Practices Dengan Tingkat Pendapatan Peternak pada Peternakan Sapi Perah Rakyat. Students e-Journal, 4(3).

[6] Lestari, P. dan Janahar M. 2001. Residu Antibiotika dalam Air Susu Sapi dan Peternakan di Jakarta. Jakarta: Pusat Penelitian dan Pengembangan Farmasi Badan Penelitian dan Pengembangan Kesehatan Departemen Kesehatan RI.

[7] Ringgita, A. 2015. Estimasi Kapasitas Tampung dan Potensi Nilai Nutrisi Daun Nanas di PT. Great Giant Pineapple Terbanggi Besar sebagai Pakan Ruminansia. Jurnal Ilmiah Peternakan Terpadu, 3(3).

[8] Siregar, Soribasya. 2001. Sapi Perah Jenis, Teknik Pemeliharaan dan Analisa Usaha. Penebar Swadaya. Jakarta.

[9] Sudono, A., R.F. Rosdiana dan B.S. Setiawan. 2003. Beternak Sapi Perah Secara Intensif. Agromedia Pustaka. Jakarta.

[10] Sugianto, A. 2008. Manajemen Ternak Perah. Fakultas Peternakan, Universitas Jendral Soedirman. Purwokerto. 